\title{
Functional Performance Measures Used for Return-to-Sport Criteria in Youth Following Lower-Extremity Injury
}

\author{
Christie Powell, Jody Jensen, and Samantha Johnson
}

\begin{abstract}
Context: As sport participation increases globally, so will injury-related risks. The process used to determine return-to-sport following injury is vital to future sport participation and injury prevention. Early specialization along with poor management of sport participation causes an increase in injury risk and potential long-term health consequences for youth athletes. Objectives: Previous injury is a common intrinsic risk factor for new injuries. Identifying functional performance deficits, defined by returnto-sport criteria, minimizes these risk factors and provides athletes with guidelines to return safely to sport. The purposes of this clinical commentary and literature review are to provide a summary of current concepts and clinical practices and to identify functional performance measures as clinical assessment tools for return-to-play criteria in the youth population. Evidence: A literature review was completed using numerous databases, where 154 relevant articles were reviewed and 22 articles were included in this commentary. Of the 22 articles using functional performance measures for return-to-sport criteria, 6 were specific to youth, 12 had mixed populations of adults and youth, and 4 were normative samples for specific youth populations. Acquisition: The gaps in the literature pertaining to functional performance measures in the youth population are addressed, and future research needs for return-to-sport criteria are identified. Evidence Synthesis: This descriptive literature review identifies 22 articles that meet the search criteria for the youth population discussing the use of clinical functional performance measures in order to identify return-to-sport criteria for lower-extremity injuries. Conclusions: Due to the inconsistencies in terminology, definitions, and standardization of clinical assessment tools, it seems necessary to create a comprehensive functional performance test battery for the lower extremity that can be used as return-to-sport criteria.
\end{abstract}

Keywords: return-to-play, pediatrics, assessment, pre-screening

\section{Context}

Sport participation and physical activity have physical, social, and psychological health benefits for children and adolescents. ${ }^{1}$ These benefits have dramatically increased participation in organized youth sport in recent years. ${ }^{2,3}$ In 2008, the National Council of Youth Sports estimated 60 million children 6-18 years of age participated in organized sport. ${ }^{4}$

Although the benefits are clear, the negative side effect to increased sport participation has been an increased rate of injury, as Monroe et $\mathrm{al}^{5}$ approximate 4 million sports and recreational injuries may occur in school-aged children in the United States. Sport is the main cause of injury in adolescents annually, with $8 \%$ of injured adolescents failing to return to recreational or organized sport due to injury. ${ }^{2}$

As sport participation increases globally, so will the number of injury-related risks. The process used to determine return-to-sport following injury is vital to future sport participation and injury prevention. Emery's ${ }^{6}$ literature review on sport-related injury concluded that injury prevention in youth sport is becoming a public health priority. Early specialization along with poor management of sport participation causes an increase in injury risk and potential long-term health consequences, including burnout, growth plate injuries, and osteoarthritis. ${ }^{7}$ Following an injury, identifying functional performance deficits, defined by return-to-sport criteria, minimizes injury risk factors and provides athletes with guidelines to participate safely in sport. ${ }^{8-10}$

The authors are with The University of Texas at Austin, Austin, TX. Powell (Championperformance@hotmail.com) is corresponding author.
Return-to-sport/play is the process of deciding when an injured athlete may safely return to practice or competition. ${ }^{11,12}$ Currently, time-based criteria found in postoperative and rehabilitation protocols are often used for return-to-sport, but after injury, many athletes are not fully recovered and return to play prematurely. Common intrinsic risk factors for lower-extremity injuries are previous injury in the same body region and compromised function. ${ }^{3,6}$ Previously injured athletes often lack the neuromuscular control, balance, proprioception, and muscular strength to return-to-sport safely. ${ }^{8,13-17}$

Currently, guidelines have not been established for return-toplay in youth athletes, as the medical and coaching community cannot reach a consensus. Several authors have addressed this problem with a return-to-sports algorithm to determine a criteriabased progression, ${ }^{18-20}$ a decision-based model for return-toplay, ${ }^{21-24}$ and a Physical Performance Assessment Checklist. ${ }^{25}$ Outside of Myer et al, ${ }^{18-20,22}$ very few studies have specifically applied these tools to the youth population as they relate to returnto-play. Numerous authors agree return-to-sport training protocols and testing criteria incorporating quantitative measures, including functional performance testing, should be used to determine lowerextremity function postinjury. ${ }^{12,26-28}$ However, reports on the application and outcomes of these protocols and tests for the youth or high school athlete are few. ${ }^{23,24}$

Manske and Reiman ${ }^{29}$ defined functional performance tests/ measures as assessments used to qualify and quantify specialized movements in sport and exercise. They can objectively measure rehabilitation progressions and determine limb asymmetries and a safe return-to-sport. ${ }^{29}$ These movement assessments are used by physicians and clinicians to determine when an athlete can safely return-to-sport following a rehabilitation program or as a 
preparticipation screening tool. The American College of Sports Medicine Summit in 2014 discussed the utility of functional movement assessments used to identify musculoskeletal injury risk and return-to-play/duty. ${ }^{28}$ The expert panel established the need for using functional movement assessments to determine readiness or returnto-play following injury and rehabilitation. ${ }^{28}$ A standardized approach to movement assessment was suggested as an effective method for injury prevention and return-to-play criteria. ${ }^{28}$

With the concept of functional movement assessment in mind, anterior cruciate ligament (ACL) injuries have received considerable attention in the last 20 years. The focus has been on preventative strategies and rehabilitation programs. Renstrom ${ }^{30}$ states that the greatest prevalence for ACL injuries exists in the female youth athlete 14-18 years of age, and considers this to be a major problem in sports medicine and an increasing clinical challenge. Numerous authors have investigated functional outcomes and deficits associated with this debilitating injury in the youth population, but they are infrequently used to determine return-to-play status. ${ }^{15,18-20,24,31-33}$ In a systematic review of adult patients with anterior cruciate ligament reconstructed (ACLR), Barber-Westin and Noyes ${ }^{27}$ found the research lacking in objective criteria for return to unrestricted sports activities. Only $4 \%$ (10/264) of the studies reviewed included functional performance measures as return-to-sport criteria. In a systematic review of ACLR, Narducci et $\mathrm{al}^{34}$ found no studies identifying movement assessment, functional performance measures, or test batteries with construct or predictive validity for return-to-sport. Teyhen et $\mathrm{al}^{28}$ found scant evidence of movement assessment and screening tools that assess functional movement, balance, and neuromuscular control deficits for both the military and the general athletic population.

\section{Objective}

This literature review discusses the necessity of functional measurement, rather than generalized time references, usually denoted in weeks or months following injury or surgery, for determining when youth athletes following lower-extremity injuries are ready to return to play. The current criteria for return-to-play are often vague, and inconsistent time-based goals inaccurately represent the athlete's functional ability to return-to-sport. ${ }^{35} \mathrm{~A}$ health professional's opinions are used to determine return-to-play status, but they often are conflicting and are not consistently founded on evidence-based research. ${ }^{36}$ The purpose of this literature review is to identify functional performance measures as clinical assessment tools for return-to-sport/play criteria in the youth population. This process of identifying functional performance deficits, defined by return-to-sport criteria, will provide the health care team with quantitative data to determine an athlete's preparedness to return-to-sport. The gaps in the literature pertaining to functional performance measures in the youth population will be addressed, and future research for return-to-play criteria will be identified.

\section{Evidence Acquisition}

This descriptive review includes studies that discuss return-tosport/play criteria using functional performance measures to quantify lower-extremity function for youth athletes. Inclusion criteria were (1) functional performance measure(s) used as objective criteria for return-to-sport/play after lower-extremity injury in youth (not measures used to determine kinematics or physical performance, or used as an intervention or outcome measure), (2) English language, and (3) published in a peer-reviewed journal.
Exclusion criteria were (1) conducted on the adult population only, (2) return-to-play criteria were used for concussions, upper-extremities, or other nonmusculoskeletal issues, (3) returnto-play was referenced as the actual time an athlete returned to sport, and (4) functional performance measures were used as an intervention. Abstracts and unpublished articles were also excluded. Two reviewers (C.P. and S.J.) independently reviewed titles and abstracts. Citation tracking of primary articles and literature reviews further determined pertinent articles.

\section{Study and Search Selection}

Data sources were found with electronic and manual literature searches. CINAHL, Academic Search Complete, SPORTDiscus, Health Source: Nursing Academic Education, and MEDLINE were considered and supplemented by the personal library of the authors. Publications selected were from 1990 to January 2016 for the youth population, and Boolean logic phrases and search terms were used for inquiry. "Return to Play" yielded N=5413, "Return-to-Sport" yielded N=2065, "Return to Athletics" yielded N =989, but when "youth" was added to the search terms, "Return to Play AND youth" yielded $\mathrm{N}=157$, NOT concussions $\mathrm{N}=32$, NOT upper extremity $\mathrm{N}=5$, and no articles met the inclusion criteria. "Returnto-Sport AND youth" yielded $\mathrm{N}=140$, NOT concussion $\mathrm{N}=19$, NOT upper extremity $\mathrm{N}=1$, and no articles met the inclusion criteria. "Return to Athletics AND youth" yielded N=5, NOT concussion $\mathrm{N}=2$, NOT upper extremity $\mathrm{N}=0$, and no articles met the inclusion criteria (Figure 1). All titles and abstracts were reviewed to determine the relevance. After searching these keywords/phrases with and without hyphens, a manual search was conducted by the authors to determine if any abstracts contained functional performance measures. Articles were manually reviewed to ensure the population included youth and adolescent athletes defined as ages 5-14 years old or "high school" age (15-19 y). Articles were included if they had mixed age groups (adults and children or high school age).

\section{Data Extraction}

Using "Return-to-Play/Sport/Athletics AND youth NOT concussion" Boolean logic phrases yielded 7 combined relevant articles, and no articles met inclusion criteria; therefore, a new search using the same Boolean phrases without "youth" AND lower-extremity NOT concussion was conducted. All titles and abstracts $(\mathrm{N}=227)$ without duplicates were reviewed by C.P. and S.J. to determine inclusion criteria. A total of 22 articles fulfilled the inclusion criteria for pooled analysis (Tables 1-3), but many were found not through database searches but through citation tracking. Additional information was gathered from related articles to gain a broader perspective on youth injuries and return-to-sport concepts.

\section{Components of Functional Performance Measures and General Use}

The most common functional performance measures used are the single-leg hop for distance, , $^{8,13,14,16,22,23,26,32,37-40,42,43,45,46,48,50,51}$ single-leg hop for time, ${ }^{8,16,23,32,42,45,48}$ single-leg triple hop for distance, $, 116,23,32,37,39,42,45,48$ single-leg triple crossover hop for distance, ${ }^{8,16,23,32,40,42,45,48}$ and vertical jump activities. ${ }^{23,24,31,37-40,44,47}$ Several authors have found that functional measures cannot detect specific lower-extremity deficits, yet can be clinically useful in assessing overall gross lower-extremity function. ${ }^{13,26,52}$ Functional 


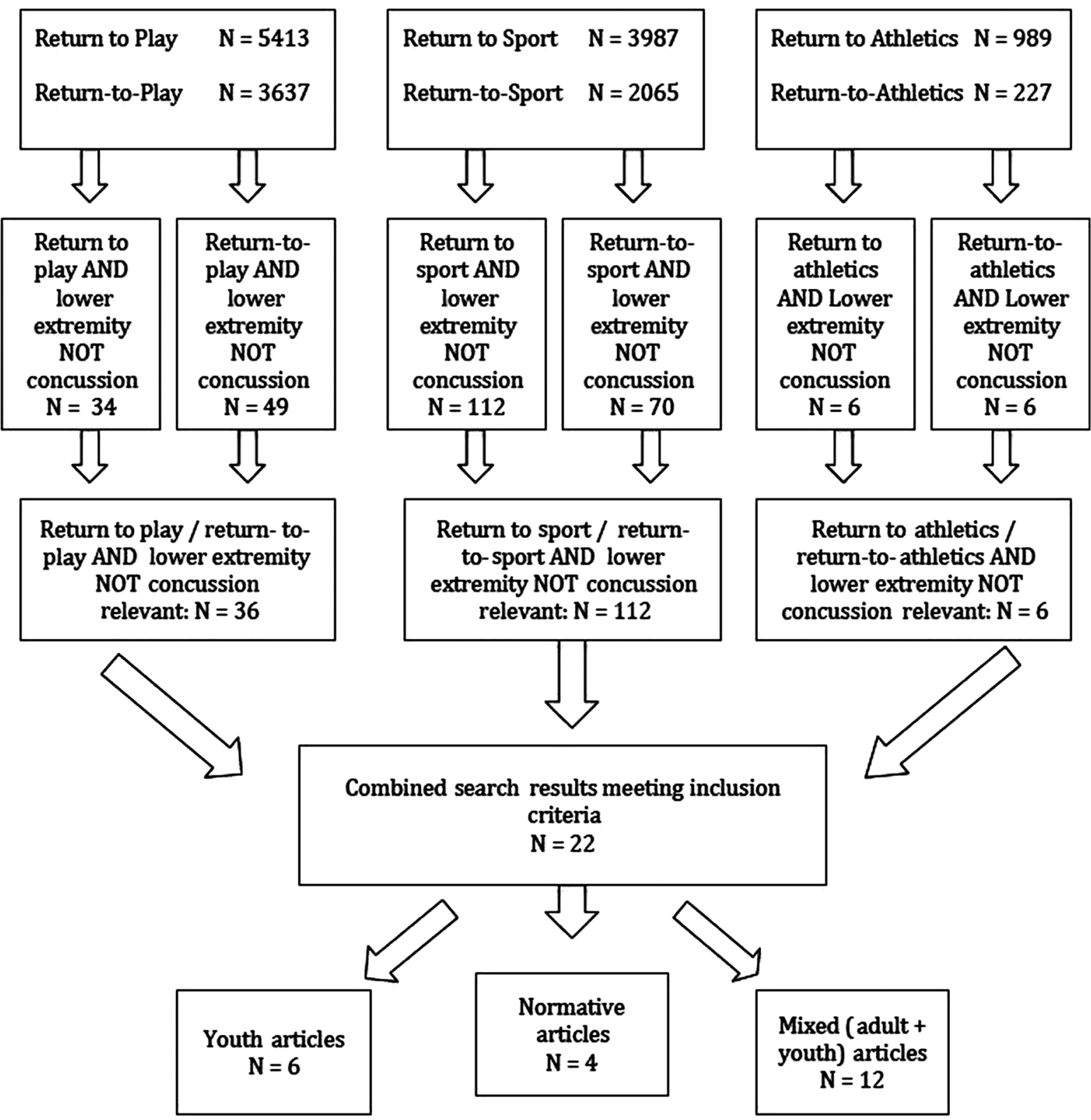

Figure 1 - Article selection using Boolean logic with primary search terms (with and without hyphens). Databases: MEDLINE, CINAHL, SPORTDiscus, Academic Search Complete, Health Source: Nursing Academic Education from 1990 to Jan 2016.

performance measures incorporate numerous variables of lowerextremity function, including neuromuscular control and coordination, ${ }^{31}$ muscular and dynamic strength, ${ }^{29,39}$ and overall dynamic joint stability. ${ }^{51}$ Many functional performance measures have been validated and demonstrate reliability, specifically the various single-leg hop tests. ${ }^{13,14,45,50,51}$

The most common clinical practice guideline for assessing functional performance measures is the limb symmetry index (LSI). The original authors, Barber et al and Noyes et al, ${ }^{13,14}$ established a cutoff point of $80 \%$ used to determine injury risk and the side-to-side differences in performance of the injured and noninjured limbs. The LSI cutoff value has been raised to $90 \%$ to $95 \%$, indicating less variance between limbs, thus reducing injury risk. ${ }^{8-10,32,39}$ Clark $^{53}$ supports the use of hop tests as clinical tools in the absence of sophisticated laboratory equipment because in a controlled environment, they best replicate the forces encountered during sport. Haines et $\mathrm{al}^{25}$ developed a Physical Performance Assessment Checklist for athletes with lower-extremity injuries in preparation for return-to-sport. The Physical Performance Assessment Checklist describes numerous constructs agreed on by an expert panel, including a battery of tests evaluating stability, neuromuscular control, and balance prior to return-to-sport. ${ }^{25}$

\section{Return-to-Play/Sport Criteria Studies for Youth and Combined Youth/Adult Populations With Lower-Extremity Injuries}

Determining when an athlete is ready to return to play following lower-extremity injury is a difficult and complicated decision for physicians and the rehabilitation team (Tables 1 and 2). 
Table 1 Articles From 1990 to Jan 2016 Using Functional Performance Measures/Objective Criteria for Return-toSport/Play for the Youth Population $(\mathrm{N}=6)$

\begin{tabular}{|c|c|c|c|c|c|}
\hline Author & Age/gender & $\begin{array}{l}\text { Injury/ } \\
\text { diagnosis }\end{array}$ & $\begin{array}{l}\text { Functional performance measure/ } \\
\text { objective criteria used }\end{array}$ & Level of evidence & Sample size \\
\hline Greenberg et $\mathrm{al}^{37}$ & $8 \mathrm{y} / \mathrm{male}$ & $\begin{array}{l}\text { Epiphyseal } \\
\text { ACLR }\end{array}$ & $\begin{array}{l}\text { (1) SLHD } \\
\text { (2) SLTHD } \\
\text { (3) SLVJ } \\
\text { (4) SL lateral hop } 12^{\prime \prime} \times 20 \mathrm{~s} \\
(\text { LSI }=90 \%)\end{array}$ & $\begin{array}{l}\text { Case study } \\
\text { Level } 4\end{array}$ & $\mathrm{~N}=1$ \\
\hline Racouillat $^{38}$ & $16 \mathrm{y} / \mathrm{female}$ & $\begin{array}{l}\text { Patellar } \\
\text { dislocation }\end{array}$ & $\begin{array}{l}\text { (1) SLHD } \\
\text { (2) VJ } \\
\text { (3) Sprint test } \\
\text { (LSI calculated) }\end{array}$ & $\begin{array}{l}\text { Case study } \\
\text { Level } 4\end{array}$ & $\mathrm{~N}=1$ \\
\hline Greenberg et $\mathrm{al}^{39}$ & $\begin{array}{l}8-15 \text { y } \\
\text { mean age: } 12.28 \text { y } \\
\text { male/female }\end{array}$ & ACLR & $\begin{array}{l}\text { (1) SLHD } \\
\text { (2) SLTHD } \\
\text { (3) SLVJ } \\
\text { (4) SL lateral hop } 12^{\prime \prime} \times 20 \mathrm{~s} \\
(\text { LSI }=90 \% \text { ) }\end{array}$ & $\begin{array}{l}\text { Retrospective case series } \\
\text { Level } 4\end{array}$ & $\mathrm{~N}=16$ \\
\hline Myer et $\mathrm{al}^{23}$ & $\begin{array}{l}14-19 \text { y } \\
\text { mean age: } 16.9 \text { y } \\
\text { male/female }\end{array}$ & ACLR & $\begin{array}{l}\text { NFL combine: } \\
\text { (1) Broad jump } \\
\text { (2) Vertical jump } \\
\text { (3) Modified pro shuttle run } \\
\text { (4) Modified agility-T } \\
\text { (5) SLHD } \\
\text { (6) SLTHD } \\
\text { (7) SLTCHD } \\
\text { (8) SLHT } \\
\text { (LSI }=90 \%)\end{array}$ & $\begin{array}{l}\text { Case control } \\
\text { Level } 4\end{array}$ & $\begin{array}{l}\mathrm{N}=18+20 \\
\text { controls }\end{array}$ \\
\hline Myer et $\mathrm{al}^{24}$ & $\begin{array}{l}15-19 \text { y } \\
\text { mean age: } 17.4 \text { y } \\
\text { male/female }\end{array}$ & ACLR & (1) VSH for $10^{\prime \prime}$ & Controlled lab study & $\mathrm{N}=33$ \\
\hline Paterno et $\mathrm{al}^{31}$ & $\begin{array}{l}13-19 \text { y } \\
\text { mean age: } 16.4 \text { y } \\
\text { male/female }\end{array}$ & ACLR & $\begin{array}{l}\text { (1) DVJ } \\
\text { (2) SLS balance }\end{array}$ & $\begin{array}{l}\text { Cohort study (prognosis) } \\
\text { Level } 2\end{array}$ & $\mathrm{~N}=56$ \\
\hline
\end{tabular}

Abbreviations: ACLR, anterior cruciate ligament reconstruction; DVJ, drop vertical jump; LSI, limb symmetry index; SL, single leg; SLHD, single-leg hop for distance; SLHT, single-leg hop for time; SLS, single-leg stance; SLTCHD, single-leg triple crossover hop for distance; SLTHD, single-leg triple hop for distance; SLVJ, single-leg vertical jump; VJ, vertical jump; VSH, vertical single-leg hop.

Table 2 Articles From 1990 to Jan 2016 Using Functional Performance Measures/Objective Criteria for Return-toSport/Play for a Mixed Sample: Youth and Adults $(N=12)$

\begin{tabular}{|c|c|c|c|c|c|}
\hline Author & Age/gender & $\begin{array}{l}\text { Injury/ } \\
\text { diagnosis }\end{array}$ & $\begin{array}{l}\text { Functional performance measure/ } \\
\text { objective criteria used }\end{array}$ & Level of evidence & $\begin{array}{l}\text { Sample } \\
\text { size }\end{array}$ \\
\hline $\begin{array}{l}\text { Björklund } \\
\text { et } \mathrm{al}^{40}\end{array}$ & $\begin{array}{l}15-50 \text { y } \\
\text { male/female }\end{array}$ & $\begin{array}{l}\text { ACLR/ACL } \\
\text { injuries } \\
\text { nonsurgical }\end{array}$ & $\begin{array}{l}\text { TAK-tests for athletes with knee injuries } \\
\text { (1) Jogging straightforward } \\
\text { (2) Fast running straightforward } \\
\text { (3) One-leg standing flexing the knee } \\
\text { (4) Rising on one leg from a seated position } \\
\text { (5) Squatting down with equal weight } \\
\text { (6) SLHD } \\
\text { (7) VSH } \\
\text { (8) SLTCHD }\end{array}$ & Reliability/validity study & $\mathrm{N}=59$ \\
\hline Clagg et $\mathrm{al}^{41}$ & $\begin{array}{l}13-27 \text { y } \\
\text { male/female }\end{array}$ & $\begin{array}{l}\text { ACLR; healthy } \\
\text { subjects }\end{array}$ & (1) SEBT modified & $\begin{array}{l}\text { Prognosis } \\
\text { Level 2b }\end{array}$ & $\mathrm{N}=113$ \\
\hline $\begin{array}{l}\text { Fitzgerald } \\
\text { et } \mathrm{al}^{32}\end{array}$ & $\begin{array}{l}15-57 \text { y } \\
\text { male/female }\end{array}$ & ACLR & $\begin{array}{l}\text { (1) SLHD } \\
\text { (2) SLTCHD } \\
\text { (3) SLTHD } \\
\text { (4) SLHT } \\
\text { (LSI }=85 \% \text { ) }\end{array}$ & Decision-making scheme & $\mathrm{N}=93$ \\
\hline
\end{tabular}


Table 2 (continued)

\begin{tabular}{|c|c|c|c|c|c|}
\hline Author & Age/gender & $\begin{array}{l}\text { Injuryl } \\
\text { diagnosis }\end{array}$ & $\begin{array}{l}\text { Functional performance measure/ } \\
\text { objective criteria used }\end{array}$ & Level of evidence & $\begin{array}{l}\text { Sample } \\
\text { size }\end{array}$ \\
\hline $\begin{array}{l}\text { Gardinier } \\
\text { et } \mathrm{al}^{8}\end{array}$ & $\begin{array}{l}(13-55) \\
\text { male/female }\end{array}$ & ACLR & $\begin{array}{l}\text { (1) SLHD } \\
\text { (2) SLTHD } \\
\text { (3) SLTCHD } \\
\text { (4) SLHT } \\
\text { (LSI }=90 \% \text { ) }\end{array}$ & Descriptive laboratory study & $\mathrm{N}=29$ \\
\hline $\begin{array}{l}\text { Hartigan } \\
\text { et } \mathrm{al}^{42}\end{array}$ & $\begin{array}{l}13-55 \text { y } \\
\text { male/female }\end{array}$ & ACLR & $\begin{array}{l}\text { (1) SLHD } \\
\text { (2) SLTHD } \\
\text { (3) SLTCHD } \\
\text { (4) SLHT } \\
\text { (LSI }=90 \% \text { ) }\end{array}$ & $\begin{array}{l}\text { Randomized clinical trial } \\
\text { Level } 2 b\end{array}$ & $\mathrm{~N}=40$ \\
\hline Herbst et $\mathrm{al}^{10}$ & $\begin{array}{l}(13-29) \\
\text { male/female }\end{array}$ & ACLR & $\begin{array}{l}\text { Back in action } \\
\text { (1) TL-ST } \\
\text { (2) OL-ST } \\
\text { (3) TL-CMJ } \\
\text { (4) OL-CMJ } \\
\text { (5) OL-SY } \\
\text { (6) TL-PJ } \\
\text { (7) TL-QFT }\end{array}$ & $\begin{array}{l}\text { Pilot study } \\
\text { Level } 3\end{array}$ & $\mathrm{~N}=69$ \\
\hline $\begin{array}{l}\text { Hildebrandt } \\
\text { et } \text { al }^{9}\end{array}$ & $\begin{array}{l}\text { Youth: } 10-19 \text { y } \\
\text { adults: } 20-50 \mathrm{y} \\
\text { male/female }\end{array}$ & $\begin{array}{l}\text { ACLR; healthy } \\
\text { subjects }\end{array}$ & $\begin{array}{l}\text { Back in action } \\
\text { (1) TL-ST } \\
\text { (2) OL-ST } \\
\text { (3) TL-CMJ } \\
\text { (4) OL-CMJ } \\
\text { (5) TL-PJ } \\
\text { (6) OL-SY } \\
\text { (7) TL-QFT }\end{array}$ & $\begin{array}{l}\text { Reliability/normative data } \\
\text { Level } 4\end{array}$ & $\mathrm{~N}=434$ \\
\hline Jang et $\mathrm{al}^{43}$ & (16-30) $\mathrm{y} / \mathrm{male}$ & ACLR & $\begin{array}{l}\text { (1) SLHD } \\
\text { (2) Co-contraction agility test } \\
\text { (3) Carioca test } \\
\text { (4) Shuttle run }(20 \mathrm{ft} \times 4 \mathrm{~s})\end{array}$ & $\begin{array}{l}\text { Retrospective comparative study } \\
\text { Level } 3\end{array}$ & $\mathrm{~N}=67$ \\
\hline Paterno et $\mathrm{al}^{44}$ & $\begin{array}{l}10-25 \text { y } \\
\text { male/female }\end{array}$ & $\begin{array}{l}\text { ACLR; healthy } \\
\text { subjects }\end{array}$ & $\begin{array}{l}\text { (1) DVJ ( } 30-\mathrm{cm} \text { box }) \\
\text { (LSI \% calculated) }\end{array}$ & $\begin{array}{l}\text { Controlled laboratory } \\
\text { Cross-sectional cohort design }\end{array}$ & $\mathrm{N}=98$ \\
\hline Paterno et $\mathrm{al}^{15}$ & $\begin{array}{l}10-25 \text { y } \\
\text { males/female }\end{array}$ & $\begin{array}{l}\text { ACLR; healthy } \\
\text { subjects }\end{array}$ & (1) Dynamic postural sway & $\begin{array}{l}\text { Controlled laboratory } \\
\text { Cross-sectional cohort design }\end{array}$ & $\mathrm{N}=98$ \\
\hline Reid et $\mathrm{al}^{45}$ & $\begin{array}{l}15-45 \text { y } \\
\text { male/female }\end{array}$ & ACLR & $\begin{array}{l}\text { (1) SLHD } \\
\text { (2) SLTHD } \\
\text { (3) SLTCHD } \\
\text { (4) SLHT } \\
\text { (LSI \% calculated) }\end{array}$ & $\begin{array}{l}\text { Prospective } \\
\text { Observational } \\
\text { Repeated measures }\end{array}$ & $\mathrm{N}=42$ \\
\hline Schmitt et al ${ }^{16}$ & $\begin{array}{l}14-25 \text { y } \\
\text { mean age: } 17.3 \mathrm{y} \\
\text { male/female }\end{array}$ & $\begin{array}{l}\text { ACLR; healthy } \\
\text { subjects }\end{array}$ & $\begin{array}{l}\text { (1) SLHD } \\
\text { (2) SLTHD } \\
\text { (3) SLTCHD } \\
\text { (4) SLHT } \\
\text { (LSI 85-90\%) }\end{array}$ & Cross-sectional study & $\mathrm{N}=90$ \\
\hline
\end{tabular}

Abbreviations: ACLR, anterior cruciate ligament reconstruction; DVJ, drop vertical jump; LSI, limb symmetry index; OL-ST, one-legged stability test; OL-SY, one-legged speedy jumps; SEBT, star excursion balance test; SL, single leg; SLHD, single-leg hop for distance; SLHT, single-leg hop for time; SLTCHD, single-leg triple crossover hop for distance; SLTHD, single-leg triple hop for distance; SLVJ, single-leg vertical jump; TL-PJ, 2-legged plyometric jumps; TL-QFT, two-legged quick feet test; TL-ST, two-legged stability test; VSH, vertical single-leg hop.

In our review of the literature, only 1 study included was not specific to an ACL injury/reconstruction (ACLR). In the case study by Racouillat, ${ }^{38}$ functional performance measures (single-leg hop for distance, vertical jump, and sprint test) were used as return-tosport criteria for a 16-year-old female lacrosse player rehabilitating from a patellar dislocation.

A case study of an 8-year-old boy included functional performance measures during the rehabilitation process and as return-tosport criteria after an all epiphyseal ACLR. ${ }^{37}$ The patient was able to achieve $90 \%$ strength symmetry and pass all return-tosport criteria using $90 \%$ LSI score by 9 months postoperatively.
Greenberg et $\mathrm{al}^{39}$ also assessed strength and functional performance recovery for 7- to 15-year-olds following ACLR and found this population may require additional rehabilitation time prior to return-to-sport due to the important characteristics unique to growth and development.

Reid et $\mathrm{al}^{45}$ support the use of and facilitate the interpretation of the most common functional performance measures and the associated LSI score for determining return-to-sport. They established the reliability and longitudinal validity of common hop tests, used as outcome measures after ACLR, for the youth and adult population $\left(15-45\right.$ y) ${ }^{45}$ 
Table 3 Articles From 1990 to Jan 2016 on Normative Data for Youth Using Functional Performance Measures/Hop Tests $(\mathbf{N}=4)$

\begin{tabular}{|c|c|c|c|c|c|}
\hline Author & Age/gender & Sport & $\begin{array}{l}\text { Functional performance measure/ } \\
\text { objective criteria used }\end{array}$ & $\begin{array}{l}\text { Level of } \\
\text { evidence }\end{array}$ & Sample size \\
\hline De Carlo and Sell ${ }^{46}$ & $\begin{array}{l}\text { Males: } \\
\text { mean age }=14.5 \mathrm{y} \\
\text { females: } \\
\text { mean age }=14.2 \mathrm{y}\end{array}$ & Multisports & $\begin{array}{l}\text { (1) SLHD } \\
\text { (LSI \% calculated) }\end{array}$ & $\begin{array}{l}\text { Normative data } \\
\text { Level } 2 \mathrm{~A}\end{array}$ & $\begin{array}{l}\mathrm{N}=2508 \\
\text { male }=1635 \\
\text { female }=873\end{array}$ \\
\hline Holm et $\mathrm{al}^{47}$ & $\begin{array}{l}7-12 \text { y } \\
\text { male/female }\end{array}$ & $\begin{array}{l}\text { Physical education } \\
\text { School activities }\end{array}$ & $\begin{array}{l}\text { (1) VJ (with upper limbs) } \\
\text { (2) VJ (without upper limbs) }\end{array}$ & $\begin{array}{l}\text { Normative data } \\
\text { Level } 2 \mathrm{~A}\end{array}$ & $\mathrm{~N}=387$ \\
\hline Myers et $\mathrm{al}^{48}$ & $\begin{array}{l}\text { Mixed sample } \\
14-24 \mathrm{y} \\
\text { mean age }=17.37 \mathrm{y} \\
\text { male/female }\end{array}$ & $\begin{array}{l}\text { High school athletes } \\
\text { Collegiate athletes } \\
\text { (basketball, soccer) }\end{array}$ & $\begin{array}{l}\text { (1) SLHD } \\
\text { (2) SLTHD } \\
\text { (3) SLTCHD } \\
\text { (4) SLHT } \\
\text { (LSI \% calculated) }\end{array}$ & $\begin{array}{l}\text { Normative data } \\
\text { Level } 2 \mathrm{~A}\end{array}$ & $\mathrm{~N}=372$ \\
\hline $\begin{array}{l}\text { Schneiders } \\
\text { et } \mathrm{al}^{49}\end{array}$ & $\begin{array}{l}\text { Mixed sample } \\
18-40 \text { y }\end{array}$ & Healthy physically active & (1) FMS & $\begin{array}{l}\text { Normative data } \\
\text { Level 2A } \\
\text { (cross-sectional) }\end{array}$ & $\mathrm{N}=209$ \\
\hline
\end{tabular}

Abbreviations: FMS, functional movement screen; LSI, limb symmetry index; SL, single leg; SLHD, single-leg hop for distance; SLHT, single-leg hop for time; SLTCHD, single-leg triple crossover hop for distance; SLTHD, single-leg triple hop for distance; VJ, vertical jump.

A decision-making scheme for returning youth and adult ACL-injured patients (15-57 y) to high-level activities, including sports or manual labor occupations, was created by Fitzgerald et $\mathrm{al}^{32}$ using common functional performance measures. This study was designed to determine candidates for nonoperative treatment of ACL injuries and create return-to-play/work criteria after an extensive rehabilitation program. The original LSI score of $80 \%$ was used, but Fitzgerald et $\mathrm{al}^{32}$ found that this needed revision to ensure a higher success rate for patients returning to high-level activities.

Clusters of functional performance measures are often used to assess the athlete as a whole and reveal deficits associated with a variety of athletic challenges. Björklund et $\mathrm{al}^{40}$ developed an extensive functional test battery-tests for athletes with knee injuries, using a mixed age range (15-50 y) - that has shown good interrater reliability and acceptable intrarater reliability. This criterion-based test was created so the physical therapist and patient could independently and simultaneously assess performance using 8 functional performance measures frequently used in rehabilitation when returning to sport following knee injuries. ${ }^{40}$ Myer et al ${ }^{18-20,24}$ have also published numerous studies with the youth population and high school athletes, investigating clinical correlates to laboratory measures and objective test batteries establishing return-to-sport criteria for use in ACL injuries. Myer et $\mathrm{al}^{23}$ utilized a modified National Football League combine test battery to identify functional deficits in athletes following ACL surgery and determined using unilateral hop tests that could identify deficits in performance for athletes attempting to returnto-sport. There is no association of time from surgery for ACLR high school athletes and deficits in unilateral force production (vertical jump height) and absorption (vertical ground reaction forces), revealing persistent side-to-side differences. ${ }^{24}$ The authors agree that there is a need to develop objective, performance-based, on-field assessment methods that can be used to determine when an athlete is safe to return-to-sport. ${ }^{23,24}$

The drop vertical jump is often used by investigators to evaluate lower limb asymmetries and neuromuscular control after ACLR to determine risk of reinjury and return-to-sport status in athletes (10-25 y). Paterno et $\mathrm{al}^{44}$ used the drop vertical jump, finding compensatory landing patterns still noted in patients at the time of return-to-sport, and was able to predict a second ACL injury after a previous ACLR. ${ }^{31}$ Out of 56 athletes with ACLR, 13 athletes between the ages of 13 and 19 years suffered a subsequent second ACL injury. Altered neuromuscular control, asymmetry in the limbs during the drop vertical jump task, and postural stability deficits were the greatest predictors of injury recurrence after a return-to-sport. ${ }^{31}$

Hartigan et a ${ }^{42}$ advise using stringent return-to-sport criteria and not time-based guidelines for athletes participating in cutting, pivoting, and jumping sports. Seven functional performance measures with strict limb symmetry scores of $90 \%$ or greater determined if athletes with ACL injuries (ages 13-55 y) could return-to-sport without surgical intervention (copers vs noncopers)..$^{42}$ Hartigan et $\mathrm{al}^{42}$ found the time required to pass all objective criteria varied greatly and found some high-level athletes were unable to pass the higher standards necessary for a safe return-to-sport 1 year following injury.

The impact of quadriceps strength deficits on 4 common functional performance measures at the time of return-to-sport on 14- to 25 -year-olds has been studied. ${ }^{16}$ Individuals with more symmetrical quadriceps strength (side-to-side differences of $10 \%$ or less and quadriceps index score of $90 \%$ or greater) demonstrated functional performance similar to that of uninjured individuals. ${ }^{16}$ It was also noted that despite being "cleared" for return-to-sport, quadriceps weakness and functional deficits were still present in these young active patients with ACLR, reiterating the need for more difficult return-to-play criteria. ${ }^{16}$

Jang et $\mathrm{al}^{43}$ included rotational stability testing in their return-tosport criteria using the carioca, co-contraction, and shuttle run tests in conjunction with the single-leg hop for distance test. Based on this study of male athletes (16-30 y) with ACLR, functional performance measures addressing dynamic rotational stability more closely mimicking sporting activities of cutting and pivoting were advised. ${ }^{43}$

Patients between the ages of 13 and 55 years with ACLR demonstrated abnormal knee contact forces during gait and returnto-sport testing with significant and meaningful joint contact force asymmetries noted during single-leg hop testing. ${ }^{8}$ These patients failed return-to-sport criteria at 6 months after ACLR, indicating increased risk for reinjury or long-term chronic knee pathologies for patients returning to sport prior to these asymmetries being addressed. 
The development of a test battery, "back in action," using functional assessments for decision making regarding return-tosport following ACLR has been established by Hildebrandt et al. ${ }^{9}$ This was the first step in creating a standardized, easy-to-use objective evaluation of knee function to facilitate the decision regarding return-to-sport. Normative data categorized by age and moderate to high reliability were established. ${ }^{9}$ Countermovement jumps, plyometric jumps, speed jumps, and agility tests were included in the functional performance test battery. Herbst et al ${ }^{10}$ then studied the clinical application of the "back in action" test battery using a $90 \%$ LSI score, establishing that most ACLR athletes did not exhibit the neuromuscular abilities, when compared with healthy controls, required to return-to-sport at 8 months postoperatively. The "back in action" test battery takes 45 minutes to complete and requires little equipment and space.

Dynamic balance and postural sway have also been used as functional performance measures determining return-to-sport criteria. Balance deficits and decreased dynamic stability have been associated with ACL injuries. Paterno et $\mathrm{al}^{15}$ used a single limb stance with eyes open on a Biodex to test dynamic postural sway and found it was significantly altered for 10 - to 25 -year-old patients with ACLR compared with healthy controls. Performance on the modified star excursion balance test was also assessed for 13- to 27-year-old patients with ACLR at the time of return-to-sport. ${ }^{41}$ Clagg et $\mathrm{al}^{41}$ found the ACLR group had lower anterior reach distances on the injured and noninjured limbs compared with the control group. The star excursion balance test has been used as a clinical tool to assess neuromuscular control deficits and dynamic stability in patients with ACLR, but the modified star excursion balance test is still being investigated.

\section{Normative Data for Youth Using Common Functional Performance Measures}

Having age-appropriate healthy normative values for a variety of functional performance measures is necessary to determine returnto-play criteria for injured and noninjured limbs. De Carlo and Sell ${ }^{46}$ found normative ranges for 2508 high-school-age males and females in a single-leg hop for distance with associated normal side-to-side variations. Abnormal functional test scores can assist medical staff in clinical decisions about returning an athlete to sport. Holm et $\mathrm{al}^{47}$ looked at muscular power in 2 different standing vertical jumps for 387 males and females between the ages of 7 and 12 years. Normative data for a battery of hop tests (single-leg hop for distance, single-leg hop for time, single-leg triple hop, and single-leg triple crossover hop) were found by Myers et $\mathrm{al}^{48}$ for a mixed population of high school and college, male and female, soccer and basketball players. They concluded that separate hop test standards should be based on participant sex and level of competition and found no clinically relevant differences between dominant and nondominant limbs. ${ }^{48}$

Normative data were established for the "back in action" test battery developed by Hildebrandt et $\mathrm{al}^{9}$ and Herbst et $\mathrm{al}^{10}$ in a 2-part study using 434 participants. The subjects were categorized according to age: children (10-14 y), youth (15-19 y), young adults (20-29y), and adults (30-50 y). Each of the 7 tests is reliable and simple to perform, and represents an important foundation for return-to-sport criteria in the clinical setting. 9,10

The functional movement screen instrument has been thoroughly studied, and normative values were established in $2011 .{ }^{49}$ Functional movement screen reference values were provided for healthy, young, active individuals ranging from 18 to 40 years. ${ }^{49}$
This test is often used to screen athletes for musculoskeletal injury and performance factors, and has been integrated into some returnto-play criteria test batteries. Determining normative values for the most reliable and valid functional performance measures can establish standardization of return-to-play criteria.

\section{Discussion}

The goal of this descriptive review was to determine useful clinical measures of function used in the youth population and to assess injury risk as it relates to return-to-sport/play criteria following lower-extremity injury. Using 5 common electronic databases, "return-to-play" search terms yielded a total of 5413 articles and "return-to-sport" yielded another 2065 articles (with some redundancy). Of the 5413 articles on "return-to-play," $157(<3 \%)$ of the articles were on youth, and none of the articles met the inclusion criteria of this study. The same was true of the 2065 articles found using the search term "return-to-sport." Of these articles, only 140 $(<7 \%)$ were on the youth population, and none of these articles met the inclusion criteria of this study. It is clear that the topic of returnto-play is well established in the literature, but when applying to the youth population and isolating lower-extremity injuries, we found only a handful of articles using a variety of search terms. The literature search yielded 22 studies from 1990 to January 2016 that described various functional performance measures or test batteries used in the youth and adult populations as return-to-sport criteria for lower-extremity injuries. These articles were difficult to find due to the inconsistencies in terminology and the focus for return-to-sport criteria on concussions and head injuries, not lower-extremity injuries. Numerous other studies investigated kinematics, kinetics, and intervention programs of the lowerextremity using functional performance measures; therefore, these articles were not included.

In 2013, Haines et $\mathrm{al}^{25}$ conducted a Delphi study that was used to develop a consensus statement on the critical constructs necessary for a comprehensive functional performance or physical performance assessment tool. The development of an instrument used to fully assess an athlete's ability to return-to-sport safely following a lower-extremity injury is essential for reducing injury risk. $^{25}$ It is imperative for functional performance measures to evaluate neuromuscular control and sports-specific or explosive movements, and to identify compensatory movements or lack of quality of movement within the demands of the activities. ${ }^{25}$ With the limited number of articles for review on this topic, clinicians and adjunct medical professionals have limited evidence-based options to determine return-to-play criteria following injury.

\section{Inconsistencies in the Literature and Limitations}

A limitation of this paper is that many articles were found by manual review; therefore, it is possible that some articles were missed. Numerous articles also measure the same performance task, such as single-leg hop for distance, but the terminology used to describe this clinical measure was not consistent. Many studies that investigated functional performance measures were not found through a database search, but by manual search within an abstract, reference list, or methodology section of other articles. For example, in the articles found manually, the terms used by the various authors that were deemed synonymous with each other include the following: functional performance tests, physical performance measures/tests, clinical outcome measures, performance outcome measures, athletic performance measures/tests, 
athletic assessments, field-based measures, field-expedient tests, functional screening tests, functional stability tests, function testing, neuromuscular indices, lower limb function, lower limb assessment, performance indices, performance aspects, physical performance tasks, task performance, motor function, motor activities, dynamic stability, performance-based functional outcome, functional determinants, and functional capacity. As there is no consensus on terminology, definition, or standardization among researchers, physicians, clinicians, coaches, and athletic trainers, a single-leg hop test (the most popular functional performance measure) could fall under any of the above-stated phrases. This makes it difficult for investigators to find appropriate literature on the topic of functional performance measures and creates confusion and inconsistencies in the administration of these measures.

\section{Recommendations for Future Research}

It is imperative to agree on definitions and terminology when describing performance measures in research, so we can accurately relay results and information and develop generalizable conclusions. Inconsistency in language makes it difficult to find information and leads to errors in interpretation.

Developing normative databases using a variety of functional performance measures is necessary to truly assess lower-extremity deficits. Currently, the LSI is commonly used to determine side-toside limb differences postinjury, ${ }^{13,14,23}$ but recently Larsen et al ${ }^{17}$ found that the noninjured limb was also impaired when compared with healthy controls 9 to 12 months after ACL surgery. This would suggest that having age-appropriate healthy normative values for a variety of functional performance measures could be used to determine return-to-play criteria for the injured and noninjured limbs. In this literature review, we found 4 articles (Table 3) describing normative data for a variety of functional performance measures in the youth population. ${ }^{46-49}$

There is a consensus about the need for further research to develop a comprehensive test battery using functional performance measures to assist in return-to-play decisions for lowerextremity injuries. Future research should focus on validating these measures and assessment tools and then extend them to the youth population.

\section{Conclusion}

This descriptive literature review identifies 22 articles that meet the search criteria for the youth population discussing the use of clinical functional performance measures used to identify return-tosport/play criteria for lower-extremity injuries (Tables 1-3). Injury prevention in youth sport is becoming a public health priority; therefore, it is imperative that we expand our efforts and research on this topic. There is an obvious need for further investigation into the use of functional performance measures in the youth population. Investigators using samples of collegiate athletes or adults have shown promising results using clinical measures for assessment of injury risk, return-to-play criteria, or as preparticipation screening tools. Because of the inconsistencies in terminology, definitions, and standardization of clinical assessment tools, it seems necessary to create a comprehensive functional performance test battery for the lower extremity that can be used as return-toplay criteria. This comprehensive assessment tool could be used for both the adult and youth populations, encompassing all the constructs needed to assess lower limb function and predict injury risk.

\section{Practice Recommendations}

1. Create consistent terminology and definitions related to functional performance measures and assessments.

2. Develop and validate a comprehensive functional performance test battery, Advanced Lower-Extremity Sports Assessment, utilizing various functional performance measures included in all the functional testing categories.

3. Extend future research to the youth population using the Advanced Lower-Extremity Sports Assessment or other comprehensive test batteries.

4. Determine normative values for the most reliable and valid functional performance measures used on various populations to create standardization of the Advanced LowerExtremity Sports Assessment or other comprehensive test batteries. ${ }^{54,55}$

\section{References}

1. Eime RM, Young JA, Harvey JT, Charity MJ, Payne WR. A systematic review of the psychological and social benefits of participation in sport for children and adolescents: informing development of a conceptual model of health through sport. Int J Behav Nutr Phys Act. 2013;10:98.

2. Albernethy L, Bleakley C. Strategies to prevent injury in adolescent sport: a systematic review. Br J Sports Med. 2007;41:627-638. doi: 10.1136/bjsm.2007.035691

3. Caine D, Maffulli N, Caine C. Epidemiology of injury in child and adolescent sports: injury rates, risk factors, and prevention. Clin J Sports Med. 2008;27:19-50. doi:10.1016/j.csm.2007.10.008

4. National Council of Youth Sports. Report on trends and participation in organized youth sports. 2008. http://www.ncys.org/pdfs/2008/2008ncysmarket-research-report.pdf. Accessed September 26, 2015.

5. Monroe KW, Thrash C, Sorrentino A, King WD. Most common sports-related injuries in a pediatric emergency department. Clin Pediatr. 2011;50:17-20. doi:10.1177/0009922810378735

6. Emery CA. Injury prevention in paediatric sport-related injuries: a scientific approach. Br J Sports Med. 2010;44(1):64-69. PubMed ID: 19945972 doi:10.1136/bjsm.2009.068353

7. DiFiori JP, Benjamin HJ, Brenner JS, et al. Overuse injuries and burnout in youth sports: a position statement from the American Medical Society of Sports Medicine. Br J Sports Med. 2014;48: 287-288. doi:10.1136/bjsports-2013-093299

8. Gardinier ES, Di Stasi S, Manal K, Buchanan TS, Snyder-Mackler L. Knee contact force asymmetries in patients who failed return-to-sport readiness criteria 6 months after anterior cruciate ligament reconstruction. Am J Sports Med. 2014;42(12):2917-2925. PubMed ID: 25318940 doi:10.1177/0363546514552184

9. Hildebrandt C, Müller L, Zisch B, Huber R, Fink C, Raschner C. Functional assessments for decision-making regarding return to sports following ACL reconstruction. Part I: development of a new test battery. Knee Surg Sports Traumatol Arthrosc. 2015;23: 1273-1281. PubMed ID: 25682164 doi:10.1007/s00167-015-3529-4

10. Herbst E, Hoser C, Hildebrandt C, et al. Functional assessments for decision-making regarding return to sports following ACL reconstruction. Part II: Clinical application of a new test battery. Knee Surg Sports Traumatol Arthrosc. 2015;23:1283-1291. PubMed ID: 25724802 doi:10.1007/s00167-015-3546-3

11. Herring S. The team physician and conditioning of athletes for sports: a consensus statement. Med Sci Sports Exerc. 2001;33(10):17891793. 
12. Herring S, Bergfeld JA, Boyd J. The team physician and return-toplay issues: a consensus statement. Med Sci Sports Exerc. 2002;34(7): 1212-1214.

13. Barber S, Noyes F, Mangine R, McCloskey J, Hartman W. Quantitative assessment of functional limitations in normal and anterior cruciate ligament-deficient knees. Clin Orthop. 1990;255:204-214.

14. Noyes FR, Barber SD, Mangine RE. Abnormal lower limb symmetry determined by function hop tests after anterior cruciate ligament rupture. Am J Sports Med. 1991;19(5):513-518. PubMed ID: 1962720 doi: $10.1177 / 036354659101900518$

15. Paterno MV, Schmitt LC, Ford KR, Rauh MJ, Hewett TE. Altered postural sway persists after anterior cruciate ligament reconstruction and return to sport. Gait Posture. 2013;38:136-140. PubMed ID: 23219783 doi:10.1016/j.gaitpost.2012.11.001

16. Schmitt LC, Paterno MV, Hewett TE. The impact of quadriceps femoris strength asymmetry on functional performance at return to sport following anterior cruciate ligament reconstruction. J Orthop Sports Phys Ther. 2012;42(9):750-759. PubMed ID: 22813542 doi: 10.2519/jospt.2012.4194

17. Larsen JB, Farup J, Lind M, Dalgas U. Muscle strength and functional performance is markedly impaired at the recommended time point for sport return after anterior cruciate ligament reconstruction in recreational athletes. Hum Mov Sci. 2015;39:73-87. PubMed ID: 25461435 doi:10.1016/j.humov.2014.10.008

18. Myer GD, Ford KR, Khoury J, Succop P, Hewett TE. Clinical correlates to laboratory measures for use in non-contact anterior cruciate ligament injury risk prediction algorithm. Clin Biomech. 2010;25:693-699. doi:10.1016/j.clinbiomech.2010.04.016

19. Myer GD, Ford KR, Khoury J, Succop P, Hewett TE. Development and validation of a clinic-based prediction tool to identify female athletes at high risk for anterior cruciate ligament injury. Am J Sports Med. 2010;38(10):2025-2033. doi:10.1177/0363546510370933

20. Myer GD, Ford KR, Khoury J, Succop P, Hewett TE. Biomechanics laboratory-based prediction algorithm to identify female athletes with high knee loads that increase risk of ACL injury. Br J Sports Med. 2011;45:245-252. PubMed ID: 20558526 doi:10.1136/bjsm.2009. 069351

21. Creighton DW, Shrier I, Shultz R, Meeuwisse WH, Matheson GO. Return-to-play in sport: a decision-based model. Clin J Sport Med. 2010;20:379-385. PubMed ID: 20818198 doi:10.1097/JSM. 0b013e3181f3c0fe

22. Myer GD, Paterno MV, Ford KR, Quatman CE, Hewett TE. Rehabilitation after anterior cruciate ligament reconstruction: criteriabased progression through the return-to-sport phase. J Orthop Sports Phys Ther. 2006;36(6):385-402. PubMed ID: 16776488 doi:10. 2519/jospt.2006.2222

23. Myer GD, Schmitt LC, Brent JL, et al. Utilization of modified NFL combine testing to identify functional deficits in athletes following ACL reconstruction. J Orthop Sports Phys Ther. 2011;41(6): 377-387. PubMed ID: 21289456 doi:10.2519/jospt.2011.3547

24. Myer GD, Martin L Jr, Ford KR, et al. No association of time from surgery with functional deficits in athletes after anterior cruciate ligament reconstruction: evidence for objective return-to-sport criteria. Am J Sports Med. 2012;40(10):2256-2263. doi:10.1177/ 0363546512454656

25. Haines S, Baker T, Donaldson M. Development of a physical performance assessment checklist for athletes who sustained a lower extremity injury in preparation for return to sport: a Delphi study. Int $J$ Sports Phys Ther. 2013;8:44-53. PubMed ID: 23439809

26. Barber SD, Noyes FR, Mangine R, DeMaio M. Rehabilitation after ACL reconstruction: functional testing. Orthopedics. 1992;15(8): 969-974.
27. Barber-Westin S, Noyes F. Systematic review with video illustration: factors used to determine return to unrestricted sports activities after anterior cruciate ligament reconstruction. Arthroscopy. 2011;27(12): 1697-1705. PubMed ID: 22137326 doi:10.1016/j.arthro.2011.09. 009

28. Teyhen D, Bergeron M, Deuster P, et al. Consortium for health and military performance and American College of Sports Medicine Summit: utility of functional movement assessment in identifying musculoskeletal injury risk. Curr Sports Med Rep. 2014;13(1):52-63. PubMed ID: 24412892 doi:10.1249/JSR.0000000000000023

29. Manske R, Reiman M. Functional performance testing for power and return to sports. Sports Health. 2013;5(3):244-250. PubMed ID: 24427396 doi:10.1177/1941738113479925

30. Renstrom P. Eight clinical conundrums relating to anterior cruciate ligament (ACL) injury in sport: recent evidence and a personal reflection. Br J Sports Med. 2013;47:367-372. PubMed ID: 22942168 doi:10.1136/bjsports-2012-091623

31. Paterno M, Schmitt L, Ford K, et al. Biomechanical measures during landing and postural stability predict second anterior cruciate ligament injury after anterior cruciate ligament reconstruction and return to sport. Am J Sports Med. 2010;38:1968-1978. PubMed ID: 20702858 doi: $10.1177 / 0363546510376053$

32. Fitzgerald G, Axe M, Snyder-Mackler L. A decision-making scheme for returning patients to high-level activity with nonoperative treatment after anterior cruciate ligament rupture. Knee Surg Sports Traumatol Arthrosc. 2000;8:76-82. PubMed ID: 10795668 doi:10. 1007/s001670050190

33. Moksnes H, Engebretsen L, Risberg M. Performance-based functional outcome for children 12 years or younger following anterior cruciate ligament injury: a two to nine-year follow-up study. Knee Surg Sports Traumatol Arthrosc. 2008;16:214-223. PubMed ID: 18157486 doi:10.1007/s00167-007-0469-7

34. Narducci E, Waltz A, Gorski K, Leppla L, Donaldson M. The clinical utility of functional performance tests within one-year post-ACL reconstruction: a systemic review. Int J Sports Phys Ther. 2011; 6(4):333-342. PubMed ID: 22163095

35. Herrington L, Myer G, Horsley I. Task based rehabilitation protocol for elite athletes following anterior cruciate ligament reconstruction: a clinical commentary. Phys Ther Sport. 2013;14:188-198. PubMed ID: 24016398 doi:10.1016/j.ptsp.2013.08.001

36. Mazer B, Shrier I, Feldman D, et al. Clinical management of musculoskeletal injuries in active children and youth. Clin J Sport Med. 2010;20(4):249-255. PubMed ID: 20606509 doi:10.1097/JSM. 0b013e3181e0b913

37. Greenberg EM, Albaugh J, Ganley TJ, Lawrence JT. Rehabilitation considerations for all epiphyseal ACL reconstruction. Int J Sports Phys Ther. 2012;7(2):185-196. PubMed ID: 22530193

38. Racouillat M. Use of plyometrics in the rehabilitation of a female lacrosse player following patellar dislocation. Orthop Phys Ther Pract. 2007;19(4):191-196.

39. Greenberg EM, Greenberg ET, Ganely TJ, Lawrence JT. Strength and functional performance recovery after anterior cruciate ligament reconstruction in preadolescent athletes. Sports Health. 2014;6(4): 309-312. PubMed ID: 24982702 doi:10.1177/1941738114537594

40. Björklund K, Skold C, Andersson L, Dalen N. Reliability of a criterion-based test of athletes with knee injuries; where the physiotherapist and the patient independently and simultaneously assess the patient's performance. Knee Surg Sports Traumatol Arthrosc. 2006; 14:165-175. PubMed ID: 15944850 doi:10.1007/s00167-005-0658-1

41. Clagg S, Paterno MV, Hewett TE, Schmitt LC. Performance on the modified star excursion balance test at the time of return to sport following anterior cruciate ligament reconstruction. J Orthop Sports 
Phys Ther. 2015;45(6):444-452. PubMed ID: 25899211 doi:10. 2519/jospt.2015.5040

42. Hartigan EH, Axe MJ, Snyder-Mackler L. Time line for noncopers to pass return-to-sports criteria after anterior cruciate ligament reconstruction. J Orthop Sports Phys Ther. 2010;40(3):141-154. PubMed ID: 20195019 doi:10.2519/jospt.2010.3168

43. Jang SH, Kim JG, Ha JK, Wang BG, Yang SJ. Functional performance tests as indicators of returning to sports after anterior cruciate ligament reconstruction. Knee. 2014;21(1):95-101. PubMed ID: 24075101 doi:10.1016/j.knee.2013.08.017

44. Paterno MV, Schmitt LC, Ford KR, Rauh MJ, Myer GD, Hewett TE. Effects of sex on compensatory landing strategies upon return to sport after anterior cruciate ligament reconstruction. J Orthop Sports Phys Ther. 2011;41(8):553-559. PubMed ID: 21808100 doi:10.2519/ jospt.2011.3591

45. Reid A, Birminham TB, Stratford PW, Alcock GK, Giffen JR. Hop testing provides a reliable and valid outcome measure during rehabilitation after anterior cruciate ligament reconstruction. Physical Ther. 2007;87(3):337-349. doi:10.2522/ptj.20060143

46. De Carlo MS, Sell KE. Normative data for range of motion and single-leg hop in high school athletes. J Sport Rehab. 1997;6: 246-255. doi:10.1123/jsr.6.3.246

47. Holm I, Fredriksen P, Fosdahl M, Vollestad N. A normative sample of isotonic and isokinetic muscle strength measurements in children 7 to 12 years of age. ACTA Paediatr. 2008;97:602-607. PubMed ID: 18355391 doi:10.1111/j.1651-2227.2008.00709.x

48. Myers BA, Jenkins WL, Killian C, Rundquist P. Normative data for hop tests in high school and collegiate basketball and soccer players. Int J Sports Phys Ther. 2014;9(5):596-603. PubMed ID: 25328822

49. Schneiders A, Davidsson A, Hörman E, Sullivan S. Functional movement screen normative values in a young, active population. Int J Sports Phys Ther. 2011;6(2):75-82. PubMed ID: 21713227

50. Bolgla L, Keskula D. Reliability of lower extremity functional performance tests. J Orthop Sports Phys Ther. 1997;26(3):138-142. PubMed ID: 9276854 doi:10.2519/jospt.1997.26.3.138

51. Fitzgerald GK, Lephart SM, Hwang JH, Wainner RS. Hop tests as predictors of dynamic knee stability. J Orthop Sports Phys Ther. 2001;31(10):588-597. PubMed ID: 11665746 doi:10.2519/jospt. 2001.31.10.588

52. Neeb TB, Aufdemkampe G, Wagener JH, Mastenbroek L. Assessing anterior cruciate ligament injuries: the association and differential value of questionnaires, clinical tests, and functional tests. J Orthop Sports Phys Ther. 1997;26(6):324-331. PubMed ID: 9402569 doi: 10.2519/jospt.1997.26.6.324

53. Clark NC. Functional performance testing following knee ligament injury. Phys Ther Sport. 2001;2:91-105. doi:10.1054/ptsp. 2001.0035

54. Moher D, Liberati A, Tetzlaff J, Altman DG; The PRISMA Group. Preferred reporting items for systematic reviews and meta-analyses: the PRISMA statement. J Clin Epidemiol. 2009;151(4):264-269. doi: 10.1016/j.clinepi.2009.06.005

55. Liberati A, Altman DG, Tetzlaff J, et al. The PRISMA statement for reporting systematic reviews and meta-analyses of studies that evaluate healthcare interventions: explanation and elaboration. $B M J$. 2009;339:b2700. doi:10.1136/bmj.b2700 